\title{
Invasive Lesion
}

National Cancer Institute

\section{Source}

National Cancer Institute. Invasive Lesion. NCI Thesaurus. Code C36117.

A malignant cellular population that has increased in size and infiltrates the surrounding tissues. 